\title{
Experimental characterisation of a cement-based compound with recycled aggregates and EPS from rehabilitation work
}

\section{Caracterización experimental del compuesto de base cemento, áridos finos y EPS reciclados de obras de rehabilitación}

\section{Mercader-Moyano, P. (Main author and Contact author)}

Universidad Sevilla. Escuela Técnica Superior de Arquitectura. Departamento de Construcciones Arquitectónicas, Sevilla, España

Av. Reina Mercedes 2, 41012 Sevilla, España. Tel.:+34 955185570

pmm@us.es

Yajnes, M. E.

Universidad de Buenos Aires. Facultad de Arquitectura, Diseño y Urbanismo. Centro Experimental de la Producción, Buenos Aires, Argentina (CEP FADU UBA)

meyarch@gmail.com

\section{Caruso, S. I.}

Universidad de Buenos Aires. Facultad de Arquitectura, Diseño y Urbanismo. Centro Experimental de la Producción, Buenos Aires, Argentina

arqas1@yahoo.com.ar

Manuscript Code: 748

Date of Acceptance/Reception: 28.08.2016/29.02.2016

Resumen

Este artículo presenta los resultados de una caracterización experimental de las propiedades físicas y mecánicas de un compuesto en base cemento que incluye áridos finos cerámicos y EPS reciclados para distintas dosificaciones procedentes de obras de rehabilitación. El objetivo es proponer un nuevo material de construcción desarrollado en Argentina para una posterior adaptación del mismo a la normativa española y europea para minimizar el impacto ambiental, mejorar la eficiencia energética y los costes de la ejecución, así como una solución al problema de gestión que suponen los residuos. Los resultados de los ensayos realizados muestran que al incrementar la cantidad de áridos y EPS reciclados, la resistencia mecánica se reduce frente a las muestras de referencia tradicionales. Al añadir EPS, se observa que se produce una disminución proporcional de la conductividad térmica, mejorando por tanto, las propiedades térmicas. Además, se obtiene que el grado de absorción del agua es similar al de las muestras de referencia y, frente al fuego, tienen un comportamiento también equivalente a éstas, obteniéndose que el nuevo material tiene baja emisión de humos y baja propagación de la llama.

Palabras clave: Árido fino reciclado, materiales de construcción, sostenibilidad, residuos de construcción y demolición, poliestireno.

\begin{abstract}
This article presents the results of an experimental characterisation of the physical and mechanical properties of a cement-based compound that includes recycled fine ceramic aggregates and EPS for various dosages from rehabilitation work. The aim of this research is to propose a new construction material, developed in Argentina, for its future adaptation to Spanish and European regulations in order to minimise the environmental impact, improve energy efficiency and reduce construction costs, as well as provide a solution to the problem that CDW (Construction and demolition waste) management represents. Tests results show that when increasing the amount of recycled fine aggregates and EPS, the mechanical resistance is reduced in comparison with traditional sample products. By adding recycled EPS, it is observed that a proportional reduction of the thermal conductivity occurs, thereby improving its thermal properties. Furthermore, it is found that the degree of water absorption is similar to that of the reference samples, and fire tests show that its behaviour is also equivalent, thereby showing that this new material has low smoke emission and low flame spread.
\end{abstract}

Keywords: Recycled fine aggregates, construction materials, sustainability, construction and demolition waste, polystyrene.

Introduction

In recent years, the construction sector has experienced intense activity which has caused enormous environmental deterioration: the excessive consumption of natural resources, the huge amounts of energy required to produce construction products, and the impact generated by the uncontrolled dumping of untreated and uncontrolled construction and demolition waste (CDW) in illegal landfills (Adnan, Bernd, \& Ehsan, 2014); (Valdés et al., 2010) (Marrero, Solís-Guzmán, Molero Alonso, Osuna-Rodriguez, \& Ramirez-de-Arellano, 2011).

In the European Union alone, the construction sector consumes $40 \%$ of natural resources for the production of construction materials (European Commission, 2013); (López-Mesa, 2009), while it generates $40 \%$ of the waste (Hendriks \& Pietersen, 2000) (Mercader-Moyano, 2012). In total, in 2008, there was an average of approximately 890 
million tons of CDW (Sáez Villoria, del Río Merino, \& et al., 2011), while the recovery rate was only 25\% (European Environmental Agency (EEA), 2002). In this context, Spain is one of the countries of the European Union that generates the most CDW: 10.2 million tons per year (European Commission, 2013).

In order to correct this situation, laws and plans at European and local levels which promote the recycling and reuse of CDW have been established (Marrero et al., 2011). In Europe, regulations have been developed by the European Framework Directive of Waste, for its prevention and reuse (PCE, 2009). However, these implemented management models remain far from achieving their goal of recycling $70 \%$ of the CDW generated in Europe by 2020, because reality shows that only 50\% is recycled (Soniego, Hestin, \& Mimid, 2010).

In Spain, the Royal Decree 105/2008 (Ministerio de la Presidencia, 2008) aims to establish the legal framework for the production and management of CDW, for its prevention, reuse and recycling. On the other hand, new energyefficiency legislative requirements of Spain, such as the Royal Decree of Energy Certification, RD 235/2013 2013 (Ministerio de la Presidencia, 2013) and the Law 8/2013 (Jefatura del Estado, 2013), regulate the basic conditions that buildings must satisfy in accordance with sustainable rehabilitation. This equates to an increase of rehabilitation and demolition work, representing an increase in the CDW generation that must be properly managed. The goal is to reduce greenhouse gases emissions by $20 \%$, achieve a contribution of renewable energy as $20 \%$ of the consumption, and improve energy efficiency by $20 \%$ by 2020.

Given this situation, finding new ways to manage CDW in order to prevent its generation and to promote its recycling has become a priority. In this context, many researchers have studied the behaviour of new materials that employ recycled aggregates from different origins as their raw materials. Among these studies, there are those which, in a cement matrix, incorporate recycled aggregates from: brick dust and ceramic tiles (Aliabdo, Abd-Elmoaty, \& Hassan, 2014)(Miličević, Bjegović, \& Siddique, 2015)(Sadek, 2012); ashes from thermal plants (Alba, Marrero, Leiva, Montes, \& Vilches, 2012); EVA waste (footwear) (De Melo \& Silva, 2013); the incorporation of waste in order to produce structural concrete (Valdés et al., 2010); and others that even produce new mortars with similar properties to traditional materials (Díaz, 2016);(Cabrera-Covarrubias, Gómez-Soberón, Almaral-Sánchez, Arredondo-Rea \& CorralHiguera, 2015).

On the other hand, other studies research into a compound of greater lightness than conventional products in order to improve the implementation of building work, and fundamentally, its thermal conductivity. One of the materials most used for this purpose has been Expanded Polystyrene, EPS, (ANPE, 2013). Among other applications, it has been employed to obtain panels on a gypsum matrix that incorporates recycled EPS aggregates (González Madariaga \& Lloveras Macia, 2008); (San-Antonio González, del Río Merino, Martónez Martónez, \& Villoria Sáez, 2014).

According to certain studies, (BASF, 2010) (INDEC, n.d.); EPS is one of the most damaging plastics for the environment because of its production volume and prolonged degradation time. At European level, from the 860 million tons of total generated construction waste, around 10\%, 940 thousand tons, comes from the field of plastics (EC, 2013). The fact that EPS waste generation has increased immeasurably in recent years (García Santos, 2009), and that in Spain, ceramic material is the second-highest group of CDW generated in construction and demolition of Spanish buildings after concrete (Mercader-Moyano, 2010); (Mercader-Moyano \& Ramírez-de-Arellano-Agudo, 2013)(MercaderMoyano, Olivares, \& Ramírez de Arellano, 2013), shows that the recycling of these residues emerges as a potential option for their management. However, a detailed study on the reuse of both materials together has yet to be carried out.

This research therefore proposes the use of fine ceramic aggregates from the rehabilitation of buildings and EPS from MSW (Municipal Solid Waste), as components of mixtures based on cement, in order to generate a compound of greater lightness while also improving its thermal properties. The aim is to propose a new construction material that includes recycled aggregates developed in Argentina for a later adaptation to Spanish and European regulations as a way of responding to the need to find a solution for waste management in the new situation arising in the community. In this regard, this research consists of the characterisation of the physical and mechanical properties of a cementbased compound of recycled fine ceramic aggregates and EPS from CDW for different dosages. The ultimate goal is to obtain the most favourable proportions and mixtures for different possible applications and to study their behaviour in tests conducted in accordance with Argentina regulations. 
For the preparation of the specimens, cement is used as the base material, and recycled fine ceramic aggregates and EPS from CDW is employed as an additive for the improvement of the properties of the newly obtained compound. To perform this experimental characterisation, the methodology that was carried out is the following:

- Study of current regulations in the country of origin: Argentina.

- Search for raw materials, processing and preparation in the laboratory.

- Preparation of the mixtures according to the various established dosages: 9 dosages that include a higher or lower percentage of recycled aggregates.

- Implementation of tests set out in the laboratory regulations, such as the IRAM standard 11561-2: Nonbearing Concrete Blocks, and 11561-3: Bearing Concrete Blocks (Instituto Argentino de Normalización y Certificación, n.d.).

- Study of the results attained in the tests in order to draw conclusions for the improvement of the products developed.

\section{Recycled materials}

The first of the recycled materials is the "rubble" which is defined in Argentina as an inert residue with rough surfaces and irregular shapes, made of ceramic materials and mortar as the result of demolition work. In accordance with the study (Yajnes \& Sutelman, 2014), rubble is classified according to its origin. For the selection of the rubble type to be used in this research, the response level is studied (high, medium or low) in accordance with 10 parameters of the 5 most common types of rubble from the worksites in Buenos Aires, Argentina: common brick with mortar, simple hollow brick without mortar of $8 / 12 \times 18 \times 33 \mathrm{~cm}$ dimensions, chippings or demolition debris, porcelain facings (monolayer stoneware, tiles/porcelain stoneware), and sanitary porcelain.

\begin{tabular}{llllll}
\multicolumn{7}{c}{ Table 1. Response level of the five types of rubble according to each parameter. Source: Self-elaboration. } \\
\hline Parameter & $\begin{array}{l}\text { Common } \\
\text { brick }\end{array}$ & $\begin{array}{l}\text { Simple } \\
\text { hollow brick }\end{array}$ & $\begin{array}{l}\text { Chippings } \\
\text { debris }\end{array}$ & $\begin{array}{l}\text { or } \\
\text { Porcelain } \\
\text { facings }\end{array}$ & $\begin{array}{l}\text { Sanitary } \\
\text { porcelain }\end{array}$ \\
\hline Contribution to the final resistance & MEDIUM & MEDIUM & MEDIUM & HIGH & HIGH \\
Workability & HIGH & HIGH & HIGH & LOW & LOW \\
Not dangerous to work with & HIGH & HIGH & HIGH & LOW & LOW \\
Ease of breaking & HIGH & HIGH & HIGH & LOW & LOW \\
Purity: homogeneity of the material & HIGH & HIGH & LOW & HIGH & HIGH \\
Percentage of usable material & MEDIUM & HIGH & LOW & HIGH & HIGH \\
Low water absorption & LOW & MEDIUM & LOW & HIGH & HIGH \\
Ease of integration with crushed EPS & HIGH & HIGH & HIGH & LOW & LOW \\
Current availability & HIGH & HIGH & HIGH & MEDIUM & LOW \\
Future availability & HIGH & HIGH & HIGH & MEDIUM & LOW \\
\hline
\end{tabular}

The results of the study are shown in Table 1. The type of waste that presents a better level of response to the parameters is common brick rubble (that selected for this research) and in second place, general chippings. Once collected, the rubble is processed in the laboratory and triturated until it passes through a sieve with holes of half an inch $(12.5 \mathrm{~mm})$ in diameter.

The second of the recycled materials used in the dosages is EPS. Its origin comes from MSW, from electronics packaging, containers, and pharmaceutical industry appliances, which are processed and crushed (Figure 1) and then sifted through a sieve with $1 / 4$-inch holes $(6.3 \mathrm{~mm})$. Expanded polystyrene is a rigid cellular plastic that uses pure hydrocarbons, which do not contain halogen, as its blowing agent.

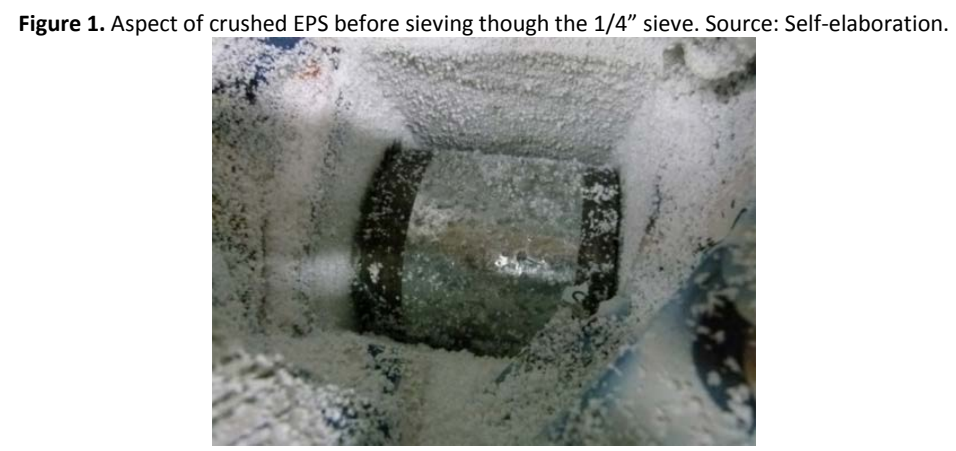




\section{Other materials}

The cement used is the habitual grey cement for the development of standard concrete in Argentina: Portland Composite Cement of 40 CPD40 strength class. It is suitable for the production of concrete elements and structures in which the acquisition of initial and final resistance is important.

\section{Samples and dosages}

Test specimens are made of various mixtures whose composition and proportion vary in terms of the additives used. Among the recycled materials (common brick rubble and EPS) that are crushed and sieved, these specimens are added to the cement, sand and water mixture, thereby developing 9 different dosages (Table 2). With the addition of EPS, the workability of the samples worsens, hence it becomes necessary to add vinyl additives (binder), such as the plasticiser "Takuru", to improve adhesion. The specimen dimensions are of $24 \times 12 \times 5 \mathrm{~cm}$ (Figure 2). Depending on the response to the tests and their characteristics, certain dosages will be used for different designed products: bearing and non-bearing blocks, and vaults for edges.

Since this is a research paper, the different dosages are studied in order to determine the different characteristics of new products. Therefore, numerous tests have been performed to establish the final dosages, which are those that provide the best response, and these are set out in the table below. It is important to note that dosages are expressed in this order: cement, sand, rubble and EPS.

Once specimens have been created with different dosages, tests are performed according to IRAM (Argentine Institute of Standardization and Certification) standards: these include water absorption, simple mechanical compaction, fire behaviour, and thermal conductivity tests.

\begin{tabular}{|c|c|c|c|c|c|c|c|c|c|c|c|c|}
\hline № & Density & Dosage & Cement & Lime & $\begin{array}{l}\text { Solid } \\
\text { Binder }\end{array}$ & Sand & Rubble & EPS & Water & $\begin{array}{l}\text { Liquid } \\
\text { Binder }\end{array}$ & Paper & Fixer \\
\hline & & & $\mathrm{kg}$ & $\mathrm{kg}$ & $\mathrm{kg}$ & $\mathrm{kg}$ & $\mathrm{kg}$ & Litres & Litres & Litres & $\mathrm{kg}$ & Litres \\
\hline 1 & 900 & 1:1:1:3.75 & 300 & & & 300 & 300 & 1125 & 150 & 9 & & \\
\hline 2 & 750 & $1: 1 / 4: 3 / 4: 3.75$ & 300 & 75 & & 225 & & 1125 & 150 & 9 & & \\
\hline 3 & 780 & 1:1/3:1:1:3.75 & 300 & 100 & & 300 & 300 & 1125 & 180 & 10.8 & & \\
\hline 4 & 1200 & 1:1/3:1:2.5 & 444 & 148 & & 44 & & 1110 & 222 & 13.3 & & \\
\hline 5 & 1200 & 1:1:2.5 & 420 & & & 420 & & 1050 & 210 & 12.6 & & \\
\hline 6 & 890 & $1: 0.5: 2: 5$ & 240 & & 120 & 480 & & 1200 & 120 & & & \\
\hline 7 & 830 & 1:0.5:1:1:5 & 240 & & 120 & 240 & 240 & 1200 & 120 & & & \\
\hline 8 & 660 & $\begin{array}{l}\text { 1:1/4:1:3/4:3.75:1 } \\
/ 3\end{array}$ & 204 & 51 & & 204 & 153 & 765 & 122 & 7.3 & 68 & 34 \\
\hline 9 & 1300 & 1:0.5:1:1:2.5 & 340 & & 170 & 340 & 340 & 850 & 170 & & & \\
\hline
\end{tabular}

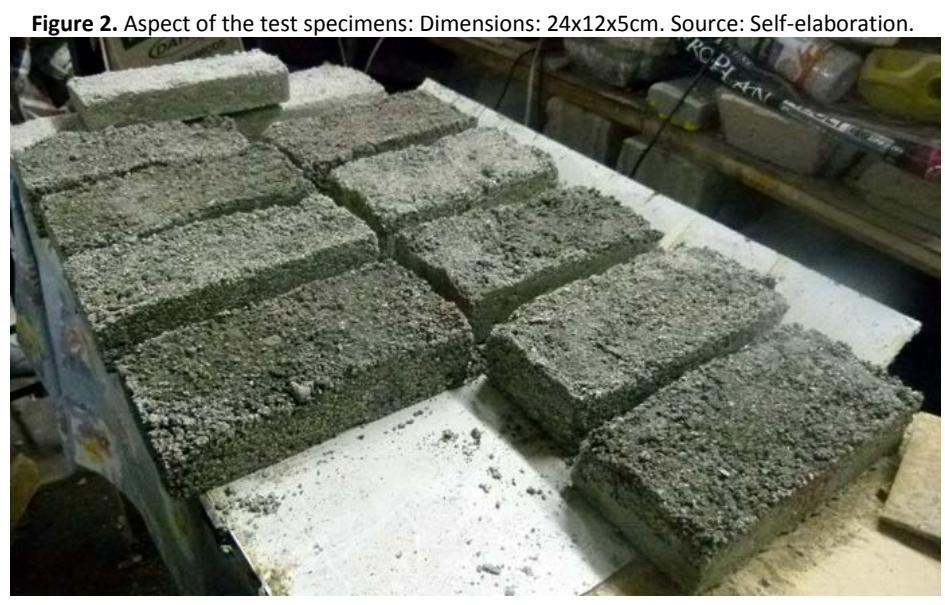




\section{Water absorption test}

Firstly, the response to water absorption is studied of the 9 specimens and traditional pieces. The aim is to analyse the incorporation of water into the mass of the samples and the amount of water that is eliminated 19 days after being removed from it, according to IRAM standard 12588 (Instituto Argentino de Normalización y Certificación, n.d.). These traditional pieces are the same as those used in other research tests and their characteristics are:

- Common exposed brick (LC) of dimensions: $11 / 5 / 22.5 \mathrm{~cm}$. Humus material baked in handcrafted ovens. Dry unit weight, $1.78 \mathrm{~kg}$. Apparent density $1440 \mathrm{~kg} / \mathrm{m}^{3}$.

- Ceramic hollow bricks (LH) of dimensions: 8/18/33 cm. Industrially baked clay material. Dry unit weight, $3.27 \mathrm{~kg}$. Apparent density, $690 \mathrm{~kg} / \mathrm{m}^{3}$.

- "Adobe" brick (LA) of dimensions: 14/6.7/28.7 cm. Stabilised soil material with cement, $10 \%$ unbaked. Dry unit weight, $3.67 \mathrm{~kg}$. Apparent density $1370 \mathrm{~kg} / \mathrm{m}^{3}$.

- Concrete block (RTKs) of dimensions: 10/26/25 cm. Concrete material. Dry unit weight, $3.7 \mathrm{~kg}$. Apparent density, 550 $\mathrm{kg} / \mathrm{m}^{3}$.

These 13 units were first weighed when they were dry and then immersed in water for 48 hours. Subsequently, they were drained and weighed at: one and two hours, and then at 5, 14 and 21 days. The water absorption graph (Figure 3) shows that all specimens, except that of mixture №8, present a similar behaviour to that of the ceramic hollow brick, in that they absorb a percentage of water between dry and wet weight between $3 \%$ and $7 \%$ at 5 days of being removed from the water and with a tendency to recover their dry weight after 21 days. Furthermore, by comparing their response to water absorption with respect to that of common brick, adobe brick and concrete blocks, it is much better, especially specimens of mixtures of higher density: №4, №5 and №9.

Figure 3. Results of water absorption test. Source: Self-elaboration.
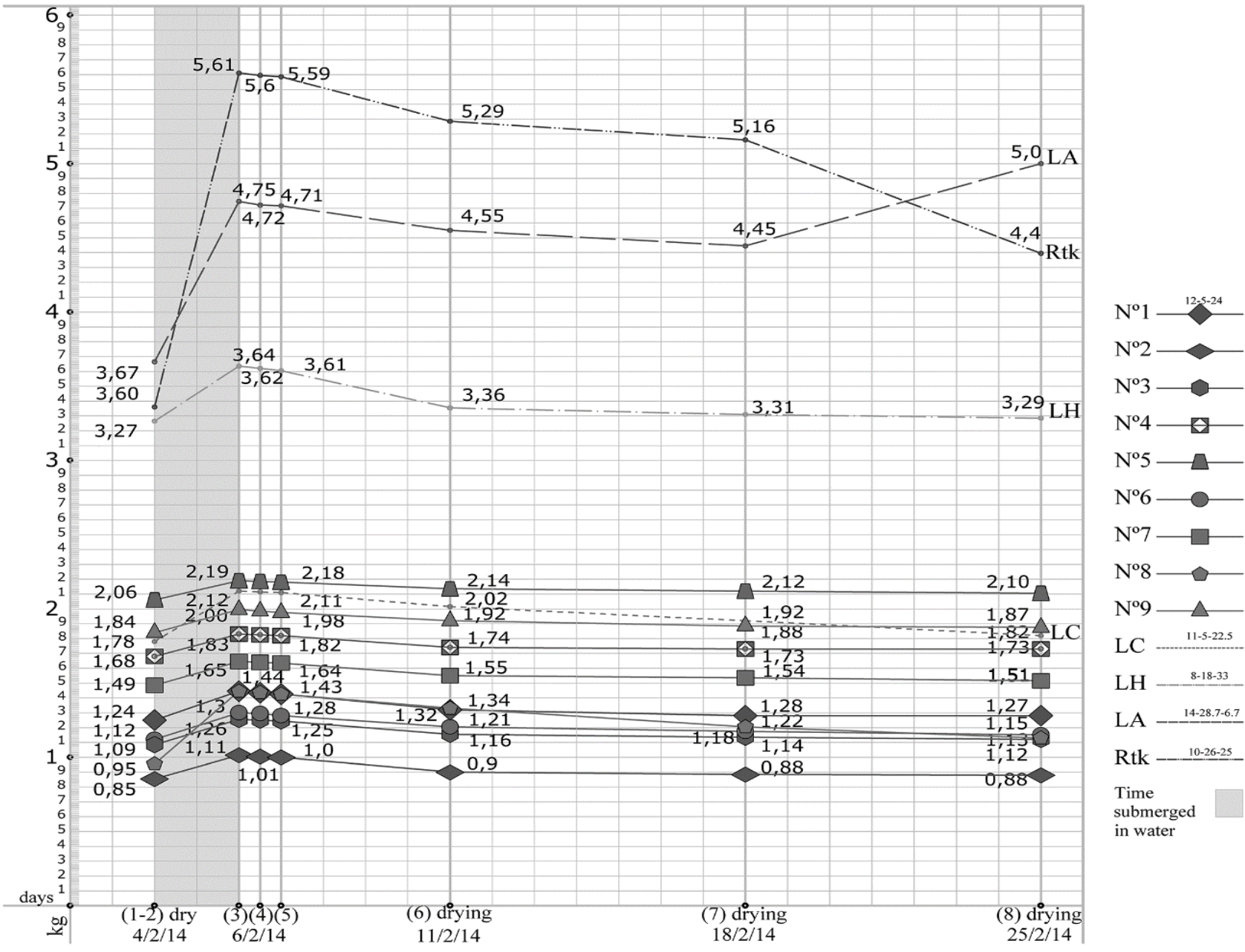


\section{Simple mechanical compaction test}

A mechanical compaction test is performed (Table 3) in which the behaviour of three blocks is tested. For this test, these blocks have nominal dimensions of $14 \times 40 \times 18 \mathrm{~cm}$ in accordance with IRAM standard 11561-4 (Instituto Argentino de Normalización y Certificación, n.d.). These three blocks have the №1 dosage, since it is the sample containing the highest percentage of recycled EPS.

\begin{tabular}{cccc} 
& \multicolumn{2}{c}{ Table 3. Results of simple mechanical compaction test. Source: Self-elaboration. } \\
\hline Dimensions (cm) & Absorption $\mathbf{( c m 2 )}$ & $\mathbf{G ~ ( k N )}$ & Tb (MPa) \\
\hline $145 \times 39.4 \times 17.7$ & 57279 & 164.7 & 2.9 \\
$14.3 \times 40.1 \times 17.6$ & 57338 & 186.6 & 3.3 \\
$14.8 \times 40.2 \times 17.8$ & 59471 & 181.0 & 3.0 \\
\hline & Gross weighted load & Breaking load & Individual pressure breaking point \\
& area of the block & of the block & of the block based on its gross section
\end{tabular}

IRAM standard 11561-3 (Instituto Argentino de Normalización y Certificación, n.d.) states that, for bearing blocks, the average resistance of the gross section is $6 \mathrm{MPa}$ and for the individual block is $5 \mathrm{MPa}$. IRAM standard 11561-2 (Instituto Argentino de Normalización y Certificación, n.d.) for non-bearing blocks, establishes that the average strength of the gross section is $2.5 \mathrm{MPa}$ and for the individual block is $2 \mathrm{MPa}$. Therefore, on considering that the chosen dosage is one that includes a higher percentage of EPS aggregates, the act of adding EPS waste affects the mechanical strength of the specimens, but when obtaining the breaking pressure of the gross section, this is limited to $3 \mathrm{MPa}$, which does not exclude them from functioning as non-bearing blocks.

Preliminary fire tests

Preliminary fire tests are conducted without taking the standards into consideration, to study the behaviour of the blocks. The temperature measurements are taken with a CA380 Canson Infrared Thermometer. Ambient conditions are maintained at a temperature of $25 \mathrm{C}$ and $60 \%$ relative humidity, as in the rest of the tests.

\section{Preliminary fire test 1}

In this test, the response to a heat source is studied of the 9 samples and traditional pieces. To this end, a direct flame is applied using a butane torch for 5 minutes at a distance of $10 \mathrm{~cm}$. In all of the pieces, EPS particles near the flame are consumed by fire but do not collapse.

\section{Preliminary fire test 2}

In this test, the behaviour of the pieces is measured when faced with heat transmission. The 9 samples and the four traditional pieces are tested through exposure to a heat source over the open top of an electric oven for one hour at a temperature of $100 \mathrm{C}$.

It is important to measure the starting temperature on both the exposed and opposite faces, but it is also a priority in this case to study the variation in heat suffered by the opposite face. Two response groups are obtained: while samples made with mixtures №4, №5 and №9 show a variation of $4.5 \mathrm{C}$ to 5 C, in the remaining cases this variation was maintained between $2 \mathrm{C}$ and $3 \mathrm{C}$. When relating this behaviour to the specific weight of different mixtures, with $1200 \mathrm{~kg} / \mathrm{m} 3$ for samples №4 and №5, and $1300 \mathrm{~kg} / \mathrm{m} 3$ for №9, no substantial differences for mixtures of between $660 \mathrm{~kg} / \mathrm{m} 3$ (№2 and №8) and $880 \mathrm{~kg} / \mathrm{m} 3$ (№1) were observed, including the intermediate densities (№3, №6, and №7).

\section{Preliminary fire test 3}

In this test, a flame is applied to one of the blocks for 60 minutes on its interior face, measuring the surface temperatures before and after the test on both the side exposed to fire and the opposite face (Figure 4). For this test, the №7 mixture is used, since this dosage has the greatest percentage of EPS.

After 30 minutes of exposure, the surface effects are displayed. Temperature rises on the exposed face from $23 \mathrm{C}$ to $387 \mathrm{C}$, while the temperature of the opposite side is constant throughout the process at $23 \mathrm{C}$, registering an increase of $3 \mathrm{C}$ after 60 minutes of exposure. When the sample is removed from the fire, the heat on the exposed face begins 
to cool immediately, recovering the initial temperature after 120 minutes, and reaches $36 \mathrm{C}$ after 60 minutes of being removed. The centre of the block passes from $23 \mathrm{C}$, at the beginning of the exposure to fire, to $27 \mathrm{C}$ after 60 minutes of exposure, reaching a peak of $40 \mathrm{C}$ after 30 minutes. It recovers its initial temperature after 120 minutes.

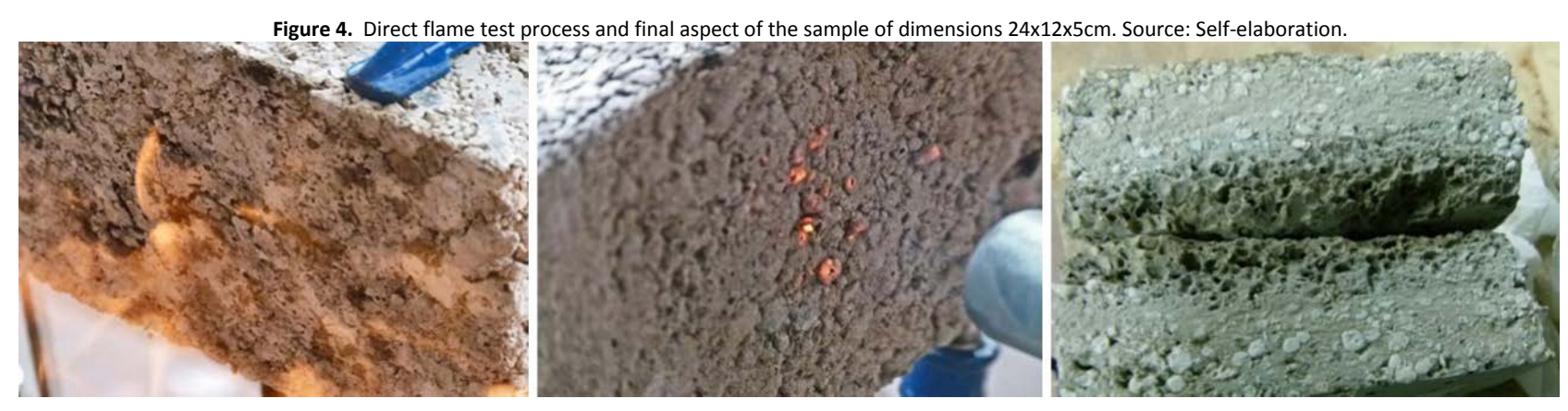

\section{Fire test performed by the INTI (Instituto Nacional de Tecnología Industrial)}

In order study the fire behaviour of the product in accordance with IRAM standards, the tests established in these regulations are performed at the INTI laboratory on blocks with mixture №1, one of the dosages that include a higher percentage of EPS aggregates.

First, the test of "Determination of Optical Density of Smoke" is performed in accordance with IRAM standard 11912 (Instituto Argentino de Normalización y Certificación, n.d.). Eight samples are tested of $7.5 \times 7.5 \mathrm{~cm}$ and $2.5 \mathrm{~cm}$ thickness. This test determines the optical smoke density. According to the value of maximum specific optical density obtained and taking into account the classification proposed by the Technical Unit of Fire Technology of the INTI, the block is classified as Level 1 (of the existing four levels): Materials that generate a low amount of smoke, with corrected optical density between 1 and 132, reaching values of 9 and 5 in flame and flameless tests, respectively.

Secondly, the "Determination of the Flame Surface Spread" test is performed according to IRAM standard 11910-3 (Instituto Argentino de Normalización y Certificación, n.d.-f). To this end, six samples are tested of $15 \times 45 \mathrm{~cm}$ with a thickness of $2.5 \mathrm{~cm}$. It is deduced that the material has a flame spread index that classifies it as RE2: materials of very low flame spread (the second-best response of the five existing after dismissing the incombustible materials). This rate of flame surface spread arises from a combination of factors derived from the speed of propagation of the flame ( $F$ ), called the factor of flame spread, and another factor related to the heat released by the tested material (Q), and called the factor of heat evolution.

\section{Thermal conductivity}

A comparison is performed of the results of thermal transmittance calculations made by the INTI of two mixtures previously developed for this research, and in accordance with the values established in the IRAM standards (Instituto Argentino de Normalización y Certificación, n.d.) for concrete with non-recycled EPS aggregates of various densities (Table 4). In this way, an approximation is sought of the potential thermal conductivity of each of the 9 mixtures. The location selected is that of the city of Buenos Aires and the block under study has a total thickness of $16.3 \mathrm{~cm}$. As this is an analysis of thermal transmittance, the other dimensions of the block are of no consequence, since, in theory, 1 $\mathrm{m} 2$ of wall is analysed. Thermal bridges are not included in the calculation since they are not established in current regulations.

Table 4. Thermal conductivity. Source: Self-elaboration.

\begin{tabular}{|c|c|c|c|c|}
\hline Name of concrete & $\begin{array}{l}\text { Sample } \\
\text { number }\end{array}$ & $\begin{array}{l}\text { Density } \\
\mathrm{kg} / \mathrm{m} 3\end{array}$ & $\begin{array}{c}\text { Vertical Lambda } \\
\mathrm{W} / \mathrm{mc}\end{array}$ & $\begin{array}{c}\text { Relation of the value of №3 and } 4 \text { samples } \\
\text { on the №2 sample }\end{array}$ \\
\hline EPS Concrete 300 & & 300 & 0.090 & \\
\hline EPS Concrete 500 & & 500 & 0.150 & \\
\hline EPS Concrete 632 & 8 & 632 & 0.170 & $13.33 \%$ \\
\hline EPS Concrete 710 & 2 and 3 & 710 & 0.180 & $20.00 \%$ \\
\hline EPS Concrete 1000 & 1,6 and 7 & 1000 & 0.260 & \\
\hline EPS Concrete 1300 & 4,5 and 9 & 1300 & 0.350 & \\
\hline
\end{tabular}


Mixtures of densities of 632 and $710 \mathrm{~kg} / \mathrm{m} 3$ are obtained from recycled aggregates, the rest are tabulated in standard materials. The first mixture has a ratio of 1:3.5, that is, 1 unit of cement per 3.5 units of crushed EPS. The second has a ratio of 1:5, 1 of cement and 5 of crushed EPS.

In Figure 5, in the abscissa, the density values of the mixtures are given, while in the ordinate, the values of conductivity are shown. The values for the established densities of standard materials $(300,500,1000,1300 \mathrm{~kg} / \mathrm{m} 3)$ can be compared with those obtained from mixtures that used recycled aggregates, which are indicated with circles. It is concluded that the mixtures obtained have similar thermal conductivity to those of concrete with virgin EPS.

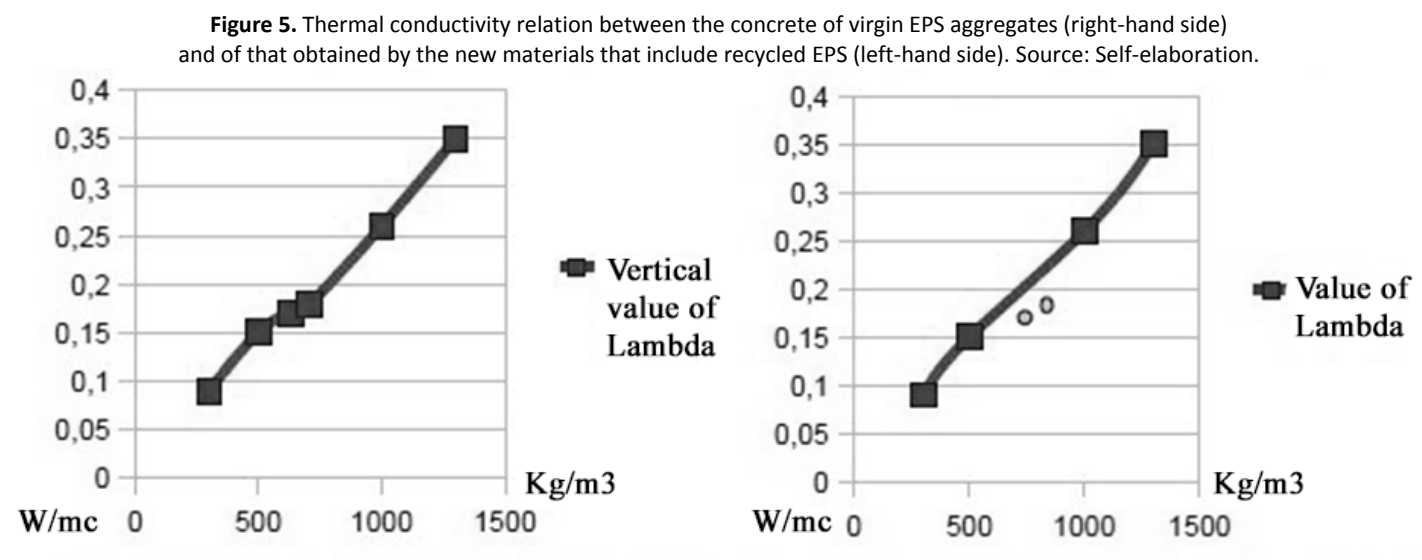

Mixtures with recycled EPS present values of lambda between 0.170 and $0.180 \mathrm{~W} / \mathrm{mc}$ : values almost equivalent to or even lower than those of the virgin EPS mixtures. It is therefore assumed that all 9 new recycled mixtures that have the B category of the IRAM standard 11601 (Instituto Argentino de Normalización y Certificación, n.d.) present acceptable thermal transmittance values within the metropolitan area of Buenos Aires.

Discussion

A new construction material is proposed that is based on cement, and recycled fine aggregates and EPS from CDW through the characterisation of its physical and mechanical properties for different dosages and whose response to the tests performed corresponds to those of similar traditional pieces. In the case of Argentina, the habitual use of CDW is in the form of aggregates of screeds: there are no studies along this line of research in the whole country, and hence this research extends the use of this type of waste as aggregates in the manufacture of new construction products.

For the creation of samples, a large amount of preparation work of the recycled added material is necessary since there is no management of CDW in Argentina, which leads to a great waste of time because of the variety and randomness in the characteristics of rubble. As other researchers argue (Garzón \& Sánchez-Soto, 2013), in order to make this process viable and industrial, it is necessary to establish proper waste management policy in that country.

For Spain, this research acquires great potential as a solution to the management problem that CDW presents, since ceramic material is one of the most profusely generated type of CDW (Mercader-Moyano, 2010); (Mercader-Moyano \& Ramírez-de-Arellano-Agudo, 2013) (Mercader-Moyano et al., 2013) and due to the current increase in EPS waste. In agreement with statements by other researchers (Bezerra, 2003), with the addition of EPS, improvements in the thermal properties of samples with respect to traditional products can be attained, and hence the inclusion of EPS in building envelopes promotes energy efficiency.

Furthermore, as other researchers conclude (Aliabdo et al., 2014); (Miličević et al., 2015)(Sadek, 2012), the addition of ceramic recycled aggregates of CDW affects the mechanical strength of the blocks, in that they significantly reduce and limit the use of the designed product to that of non-bearing blocks. Furthermore, with the addition of these ceramic aggregates, then the water absorption is increased; when EPS is added to the samples, the water absorption remains similar to that of traditional products: almost identical to the degree of water absorption of a common brick. 
The experimental characterisation of this new construction material based on cement, recycled fine aggregates and EPS of CDW from rehabilitation work reveals that:

- The addition of recycled EPS aggregates hinders the adhesion of the mixtures with respect to the reference materials without these aggregates. It is therefore necessary to increase the water-cement ratio and to incorporate vinyl additives that improve the conglomeration of the mixtures.

- The addition of EPS in the mixture reduces the degree of water absorption in comparison with samples with only ceramic aggregates added. The ceramic aggregate samples provoke a better response than those of "adobe" bricks, concrete blocks, and simple hollow bricks, since they obtain similar behaviour to that of common bricks.

- In relation to the mechanical characteristics of the material, it is concluded that the compressive strength of the block decreases with the addition of EPS and recycled ceramic aggregate, but its results comply with the minimum values set in Argentine regulations, and hence this new product can function as the material for non-bearing blocks on the façade of a building.

- Regarding fire behaviour, despite the addition of EPS, these samples are classified as materials with very low smoke emissions and low flame spread.

- The addition of EPS in the mixture improves the thermal conductivity of the block with respect to traditional pieces, thus the thermal properties of recycled blocks are improved. Even when recycled EPS is used, the lambda values are equivalent to or even lower than those of the samples that include virgin EPS.

\section{Acknowledgements}

This research is part of the international research project: REEB "Rehabilitación ecoeficiente de edificios y barriadas: la gestión de los RCD en Argentina y la aplicación de productos ecoeficentes del CEP a la normativa Española" (reference CCPI2015), type "Convenio Colaboración Proyecto Internacional" included in the specific research agreement between the University of Seville and Buenos Aires. Of the many people who have participated in this research, a special mention is deserved for the architects Silvana Sutelman, Lucia Tosi, Ida Pecorelli, Pablo Azqueta, and Ricardo Tartaglia.

Adnan, E., Bernd, K., \& Ehsan, R. (2014). Evaluación de los impactos medioambientales de los proyectos de construcción. Revista Ingeniería de Construcción, 29, 234-254. https://doi.org/10.4067/S0718-50732014000300002

Alba, M. D., Marrero, M., Leiva, C., Montes, M. V, \& Vilches, L. (2012). Empleo de paneles compuestos por subproductos de centrales térmicas en fachadas trasdosadas. Informes de La Construcción, 64(526), 179-190. https://doi.org/10.3989/ic.10.042

Aliabdo, A. A., Abd-Elmoaty, A. E. M., \& Hassan, H. H. (2014). Utilization of crushed clay brick in concrete industry. Alexandria Engineering Journal, 53(1), 151-168. https://doi.org/10.1016/j.aej.2013.12.003

Asociación Nacional de Poliestireno Expandido. (2013). Eficiencia y compromiso: Logros en la gestión del residuo de EPS. Futuro En Vivo, Julio.

BASF. (2010). Informe España 2010.

Bezerra, L. A. C. (2003). Análise do desempenho térmico de sistema construtivo de concreto com eps como agregado graúdo. Thesis, Universidade Federal do Rio Grande do Norte, Natal.

Cabrera-Covarrubias, F. G., Gómez-Soberón, J. M., Almaral-Sánchez, J. L., Arredondo-Rea, S. P., \& Corral-Higuera, R. (2015). Mechanical properties of mortars containing recycled ceramic as a fine aggregate replacement. Revista de La Construccion, 14(3), 22-29. http://dx.doi.org/10.4067/S0718-915X2015000300003.

De Melo, A. B., \& Silva, E. P. (2013). Lightweight concrete blocks with EVA recycled aggregate: a contribution to the thermal efficiency of building external walls. Materiales de Construcción, 63(312), 479-495. https://doi.org/10.3989/mc.2013.05912

Díaz, N. (2016). Analysis of the properties of masonry mortars made with recycled fine aggregates for use as a new building material in Cuba. Revista de La Construccion, 15(1), 9-21. http://dx.doi.org/10.4067/S0718-915X2016000100001

European Commission. (2013). Eurostat Report. European Commission.

European Environmental Agency (EEA). (2002). Review of Selected Waste Streams. (European Environmental Agency, Ed.). Copenhagen, Denmark.

García Santos, A. (2009). Escayola reforzada con fibras de polipropileno y aligerada con perlas de poliestireno expandido. Materiales de Construcción, 59(293), 105-124. https://doi.org/10.3989/mc.2009.41107

Garzón, E., \& Sánchez-Soto, P. J. (2013). Planificación de recogida y flujo de residuos sólidos mediante la utilización de una herramienta informatizaca para su gestión sostenible. Boletín de La Sociedad Española de Cerámica Y Vidrio, Sept-Oct, 5-15. 
González Madariaga, F. J., \& Lloveras Macia, J. (2008). Mezclas de residuos de poliestireno expandido (EPS) conglomerados con yeso o escayola para su uso en la construcción. Informes de La Construcción, 60(509), 35-43. https://doi.org/10.3989/ic.2008.v60.i509.589

Hendriks, C. F., \& Pietersen, H. S. (2000). Sustainable Raw Materials: Construction and Demolition Waste. Cachan Cedex, France: RILEM Publication.

Norma IRAM 11.561: Bloques de Hormigón (2012). Instituto Argentino de Normalización y Certificación.

Norma IRAM 11561-2: Bloques no portantes de hormigón (1997). Instituto Argentino de Normalización y Certificación.

Norma IRAM 11561-3: Bloques portantes de hormigón (2012). Instituto Argentino de Normalización y Certificación.

Norma IRAM 11561-4: Bloques de hormigón. Métodos de ensayo. (1997). Instituto Argentino de Normalización y Certificación.

Norma IRAM 11601: Aislamiento térmico en edificios. Métodos de cálculo. (2002). Instituto Argentino de Normalización y Certificación

Norma IRAM 11605: Acondicionamiento térmico edificios. (1996). Instituto Argentino de Normalización y Certificación

Norma IRAM 11910-3: Determinación Propagación Superficial de Llama. (1994). Instituto Argentino de Normalización y Certificación.

Norma IRAM 11912: Determinación de la Densidad Óptica de Humos. (1995). Instituto Argentino de Normalización y Certificación

IRAM (1982). Instituto Argentino de Normalización y Certificación. Norma IRAM 12588: Ladrillos y bloques cerámicos para la construcción de muros. Método de ensayo de la resistencia a la intemperie. Capacidad de absorción de agua por inmersión en agua fría y por inmersión en agua hirviendo. IRAM

Instituto Nacional de Estadística y Censos (INDEC). (n.d.). Estudio sobre los plásticos en la República Argentina. Instituto Nacional de Estadística y Censos

Jefatura del Estado. Ley 8/2013, de 26 de junio, de rehabilitación, regeneración y renovación urbanas. (2013). España.

López-Mesa, B. (2009). Comparison of environmental impacts of building structures with in situ cast floors and with precast concrete floors. Building and Environment, 44(4), 669-712. https://doi.org/10.1016/j.buildenv.2008.05.017

Marrero, M., Solís-Guzmán, J., Molero Alonso, B., Osuna-Rodriguez, M., \& Ramirez-de-Arellano, A. (2011). Demolition Waste Management in Spanish Legislation. The Open Construction and Building Technology Journal, 5(1), 162-173. https://doi.org/10.2174/1874836801105010162

Mercader-Moyano, P. (2010). Cuantificación de los recursos consumidos y emisiones de CO2 producidas en las construcciones de Andalucía y sus implicaciones en el protocolo de Kioto. Construcciones Arquitectónicas I. Thesis, Universidad de Sevilla, Spain.

Mercader-Moyano, P. (2012). Cuantificación de los recursos materiales consumidos en la ejecución de la cimentación. Informes de La Construcción, 62(514), 125-132. https://doi.org/10.3989/ic.09.000

Mercader-Moyano, P., Olivares, S., \& Ramírez de Arellano, A. (2013). Modelo de cuantificación del consumo energético en edificación. Materiales de Construcción, 62(308), 567-582. https://doi.org/10.3989/mc.2012.02411

Mercader-Moyano, P., \& Ramírez-de-Arellano-Agudo, A. (2013). Selective classification and quantification model of C\&D waste from material resources consumed in residential building construction. Waste Management \& Research, 31(5), 458-74. https://doi.org/10.1177/0734242X13477719

Miličević, I., Bjegović, D., \& Siddique, R. (2015). Experimental research of concrete floor blocks with crushed bricks and tiles aggregate. Construction and Building Materials, 94, 775-783. https://doi.org/10.1016/j.conbuildmat.2015.07.163

Ministerio de la Presidencia. Real Decreto 105/2008 por el que se regula la producción y gestión de los residuos de construcción y demolición. (2008). España.

Ministerio de la Presidencia. Real Decreto 235/2013, de 5 de abril, por el que se aprueba el procedimiento básico para la certificación de la eficiencia energética de los edificios. (2013). España.

Parlamento y Consejo Europeo. Directiva 2008/98/CE sobre los residuos. (2009). España.

Sadek, D. M. (2012). Physico-mechanical properties of solid cement bricks containing recycled aggregates. Journal of Advanced Research, 3(3), 253260. https://doi.org/10.1016/j.jare.2011.08.001

Sáez Villoria, P., del Río Merino, M., Porras-Amores, C., and San-Antonio-Gonzalez, A. (2011). Construction and demolition waste generation and recycling rates in Europe. Legal measures to improve their management. In 4th International Congress on Energy and environment engineering and management. Mérida.

San-Antonio González, A., del Río Merino, M., Martónez Martónez, P., \& Villoria Sáez, P. (2014). Properties of lightweight plaster materials made with expanded polystyrene foam (EPS). In Construction and Building Research (pp. 413-417). Springer Netherlands. https://doi.org/10.1007/978-94-007-7790-3_50

Soniego, P., Hestin, M., \& Mimid, S. (2010). Management of construction and demolition waste in the EU. In European Stakeholders Workshop. Brussels: Bio intelligence service.

Valdés, A. J., Martínez, C. M., Romero, M. I. G., García, B. L., Pozo, J. M. M., \& Vegas, a T. (2010). Re-use of construction and demolition residues and industrial wastes for the elaboration or recycled eco-efficient concretes. Spanish Journal of Agricultural Research, 8(1), 25-34. https://doi.org/10.5424/sjar/2010081-1140

Yajnes, M., \& Sutelman, S. (2014). El camino del cascote en la ciudad de Buenos Aires [Informe]. 